\title{
ALA Representatives
}

\section{AT INAUGURATIONS, DEDICATIONS AND OTHER ACADEMIC CEREMONIES}

On Oct. 8 Warren Boes represented ALA at the inauguration of Albert Edward Holland as president of Hobert and William Smith Colleges; and on Oct. 20 Andrew J. Eaton attended the inauguration of John Anthony Brown, Jr., as president of Lindenwood College. At the inauguration of Elwin Lloyd Skiles as president of Hardin Simmons University on Nov. 7, Perma A. Rich represented ALA. Sister Jeanne d'Arc represented ALA at the inauguration of Elizabeth K. McCormack as president of the College of the Sacred Heart in Manhattanville, N.Y, on Dec. 9.

On Jan. 14 Wilbur F. Helmbold attended ceremonies inaugurating James Huey Edmondson as president of Judson College in Marion, Ala.; on Feb. 13, ALA was represented by Guy Lyle at the Centennial celebration of Morehouse College. Foster E. Mohrhardt represented ALA at the Charter Day Centennial celebration of Howard University on March 2; and James R. O'Rourke was the ALA representative at the inauguration of Karl Kenneth Wilson as president of Asbury College on March 28.

On April 2, Edmon Low attended the investiture of Granville Oral Roberts as president of Oral Roberts University. Ray S. Barker represented ALA at the Centennial Convocation at Johnson C. Smith University on April 7; on April 8, Herbert B. Anstaett attended the Lebanon Valley College Centennial Convocation; and on April 14, H. William Axford, the Academic Festival at Colorado Women's College honoring its founders and benefactors, and

\section{Conference on Junior College Libraries} JUNE 21-24, 1967

University of California, Los Angeles

For program and registration information refer to ALA Bulletin, May 1967, pp. 473-74. Fees are:

$\$ 60$ for registration with single room

$\$ 55$ for registration with dougle room

$\$ 40$ for registration with meals only (except breakfast)

Registration fee should be mailed immediately to

Miss Harriett Genung

Chairman, Junior College Libraries Section

P.O. Box 111, Rural Station

Mt. San Antonio College

Walnut, California 91789 celebrating its renaming as Temple Buell College.

Mrs. Ruth W. Pinkerton was the ALA representative at the inauguration of G. Wayne Glick as president of Keuka College on April 15; on that date also, Herbert Anstaett represented ALA at the inauguration of Morley J. Mays as president of Elizabethtown College; and Jerrold Orne, at the inauguration of E. Bruce Heilman as president of Meredith College. Edward H. Elliott represented ALA at the Skidmore College Honors Convocation on April 18; and at the inauguration of John Carrier Weaver as president of the University of Missouri on that date Ralph S. Emerick was the ALA representative.

At the University of South Dakota inauguration of Edward Quentin Moulton as president on April 21 Kordillia C. Johnson was in attendance; on April 22, Emerson Jacob represented ALA at the inauguration of Chester T. McNerney as president of Edinboro State College, Edinboro, Penna; and on that date also John L. Glinka attended the inauguration of James Edward Doty as president of Baker University; and Victoria Hargrave, the inauguration of Glenn Lowery McConagha as president of Blackburn College.

At the inauguration of Leonard L. Holloway as president of Mary Hardin-Baylor College on April 25, James H. Rogers represented ALA; and on April 29, Katharine M. Stokes was the representative to the University of Michigan International Conference on Higher Education in Tomorrow's World, and Commencement Convocation. Elizabeth C. Welborn attended the inauguration of Joseph Wightman as president of Erskine College on that date.

On May 2, Juliet B. Clark represented ALA at ceremonies inaugurating John Summerskill as president of San Francisco State College; on May 6, Mrs. Lillian H. Smoke, at dedication ceremonies of the new campus of Hagerstown Junior College; Peter Spyers-Duran, at the inauguration of Bernard Schroeder Adams as president of Ripon College; Rice Estes, at the dedication of Hofstra University Library, and John $\mathrm{O}$. Bronson, at the inauguration of Frank N. Philpot as president of Athens College, Athens, Ala. On May 7, Robert W. Orr attended dedication ceremonies of Cowles library, Drake University; and on May 8, Tyrus G. Harmsen, the inauguration of John Alden Greenlee as president of California State College in Los Angeles.

Frederick H. Wagman attended the dedication of the new library at Eastern Michigan 
University on May 12; on May 13, Beverly T. Moss represented ALA at the inauguration of William Lincoln Giles as president of Mississippi State University. At Chico State College, Chico, Calif., on May 20, Gordon Martin attended as ALA representative the inauguration of Robert Eugene Hill as president of the College; and at State University of New York at Buffalo, on May 29, John R. Russell, the inauguration of Martin Mayerson as president of the university.

\section{ACRL EXHIBIT BOOTH}

ACRL will again provide an exhibit booth (No. 243) at the ALA conference in San Francisco. The booth will serve as a center of information about ACRL activities, including publications and reprints of interest to academic and research librarians. Inquiries for information can be answered by academic librarians who are staffing the booth, or left for answering by the ACRL executive secretary after he returns to the ALA headquarters in July.

The ACRL booth is being manned by academic librarians of the San Francisco Bay area under the supervision of Juliet B. Clark, acting university librarian, University of San Francisco, and chairman of the ACRL Committee on Local Arrangements.

Special emphasis is being provided in two areas of ACRL activity:

1. The ACRL Audio-Visual Committee will provide information relative to the purpose and activities of the committee, as well as books, articles and other items on the establishment, use, promotion and evaluation of audio-visual materials and services, primarily in academic libraries. Committee members and consultants will be present to answer questions and offer assistance to delegates interested in $\mathrm{A}-\mathrm{V}$ problems and programs.

2. The Junior College Libraries Section of ACRL will provide copies of bibliographies, surveys, and other information of interest to junior college librarians for assistance in development of effective library programs. Sample copies of handbooks will be available for browsing. Members of the Section also plan to assist in the staffing of the booth, to act as consultants.

The booth, located in Brooks Hall, will be open from Sunday, June 25, through Thursday, June 29, during the regular exhibit hours.

ACRL Membership: April 30, 1967

10,978

April 30, 1966

9,669

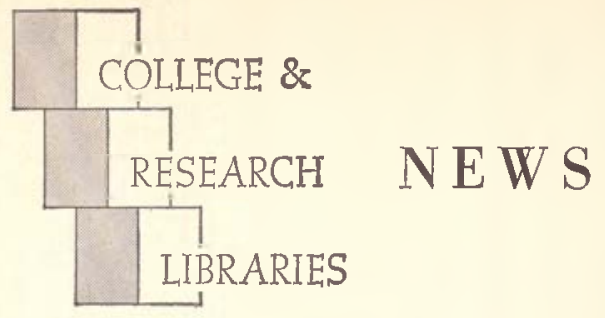

ACRL News Issue of College \& Research Libraries

Editor, David Kaser, Joint University Libraries, Nashville, Tenn. 37203.

Publications Officer, Mary Falvey, 50 E. Huron St., Chicago 60611.

ACRL Executive Secretary, George M. Bailey.

ACRL Officers, 1966/67: President, Ralph E. McCoy College Libraries Section Chairman, Lee Sutton; Junio College Libraries Section, Harriett Genung; Rare Books Section, William H. Runge; Subject Specialists Section, Mary E. Schell; Agriculture and Biological Sciences Subsection Chairman, Roy L. Kidman; Art Subsection, Mrs. Kathryn Blackwell; Law and Political Science Subsection, Jane Wilson; Slavic and East European Subsection, Bohdan S. Wynar; University Libraries Section Chairman, John M. Dawson.

Editorial Board: JoHn M. Dawson, University of Delaware; Gustave A. Harrer, Boston University; SaMvel RothsteIn, University of British Columbia; James E. Skipper, Princeton University; Norman E. Tanis, Kansas State College of Pittsburg; Maurice F. Tauber, Columbia University; EILeEN Thonnton, Oberlin College.

News from the Field, Personnel profiles and notes, classified advertising, official matter of ACRL, and other material of a timely nature is published in the News issues of College \& Research Libraries.

Inclusion of an article or advertisement in CRL does not constitute official endorsement by ACRL or ALA Production and Advertising and Circulation office: 50 E. Huron St., Chicago, IIl. 60611. Change of address and orders for subscriptions should be addressed to College \& Research Libraries, for receipt at the above address, at least two months before the publication date of the effective issue.

Subscription to $C R L$ is included in membership dues to $A C R L$ of $\$ 6$ or more; other subscriptions to $C R L$ are $\$ 10$ per year. Neither subscriptions nor memberships include miscellaneous unscheduled supplements, which are available by purchase only. Retroactive subscriptions are not accepted. Single journal copies are available at $\$ 1.50$ each and News issues at $\$ 1.00$ each from ALA Publishing Department.

Indexed in Library Literature. Abstracted in Library Science Abstracts. Book reviews indexed in Book Re view Index.

College \& Research Libraries, is the official journal of the Association of College and Research Libraries, division of the American Library Association; and is published seventeen times per year-bi-monthly as a technical journal with 11 monthly News issues, combining July-August-at 1201-05 Bluff St., Fulton, Mo. 65251 .

Second-class postage paid at Fulton, Mo. and at additional mailing offices. 